\title{
Stability Analysis in Soybean [(Glycine max L.) Merrill]
}

\author{
Shruti Koraddi*, G.T. Basavaraja and Ishwar Bhoodi \\ Department of Genetics and Plant Breeding, ANGRAU, Agricultural College, Bapatla, India \\ *Corresponding author
}

\section{A B S T R A C T}

\begin{tabular}{|l|}
\hline K e y w or d s \\
G X E interaction, \\
$\begin{array}{l}\text { Soybean, Stability } \\
\text { analysis. }\end{array}$ \\
\hline Article Info \\
\hline $\begin{array}{l}\text { Accepted: } \\
\text { 17 July } 2017 \\
\text { Available Online: } \\
\text { 10 September } 2017\end{array}$
\end{tabular}

The present investigation was carried out to study stability performance over three environments for seed yield and its components in 13 advanced breeding lines (including five parents) of soybean using a randomized complete block design. The partitioning of (environment + genotype $\mathrm{x}$ environment) mean squares showed that environments (linear) differed significantly and were quite diverse with regards to their effects on the performance of genotypes for seed yield and majority of yield components. Stable genotypes were identified for wider environments and specific environments with high per se performance (over general mean) for seed yield per ha. On the basis of stability analysis of individual characters, the genotype DSb 21 was identified as stable genotype for all the characters studied with higher mean across environments. For seed yield, genotype DSb 23-2 was high yielder across environments compared to the check JS 335.

\section{Introduction}

Soybean [(Glycine max. L.) Merrill] designated as the "miracle bean" has established its potential as an industrially vital and viable oil seed crop in many areas of India. The yield level has not been achieved in tropical countries like India, where low productivity is mainly due to the short growing periods available in subtropical conditions, limited varietal stability, and narrow genetic base of soybean cultivars (Singh and Hymowitz, 2001). Crop yield fluctuates due to suitability of varieties to different growing seasons or conditions. A specific genotype does not always exhibit the same phenotypic characteristics under all environments and different genotypes respond differently to a specific environment. Gene expression is subject to modification by the environment; therefore, genotypic expression of the phenotype is environmentally dependent (Kang, 1998). The development of new cultivars involves breeding of cultivars with desired characteristics such as high economic yield, tolerance or resistance to biotic and abiotic stresses, traits that add value to the product, and the stability of these traits in target environments. Inconsistent genotypic responses to environmental factors such as temperature, soil moisture, soil type, or fertility level from location to location and year to year are a function of genotype environment (GE) interactions. Genotype $\mathrm{x}$ environment interactions have been defined as the failure of genotypes to achieve the same relative performance in different environments (Baker, 1988). Identification of 
yield-contributing traits and knowledge of GE interactions and yield stability are important for breeding new cultivars with improved adaptation to the environmental constraints prevailing in the target environments. To avoid genetic vulnerability associated with the narrowing of the genetic base of any crop, the GE interactions of the germplasm are important (Kang, 1998). Therefore, in the present investigation an attempt has been made to evaluate soybean genotypes for yield and its component characters under different environments to identify genotypes with suitable performance in variable environments.

\section{Materials and Methods}

The materials for the present study comprised of eight advanced breeding lines which are cross derivatives of JS 335 x EC 241778, JS $335 \times$ EC 241780, JS 93-05 x EC 241780, DSb 12 x EC 241780 along with their five parents was laid out in a replicated trial at three locations viz., Main Agricultural Research Station, Dharwad, Agricultural Research Station, Bailhongal and Research \& Development Farm, Ugar Sugar Works, Ugarkhurd, during kharif 2013. The trials were conducted in randomized complete block design replicated thrice in each environment each line was sown in 3 rows of 4 meter length, with a spacing of $30 \mathrm{~cm}$ between the rows and $10 \mathrm{~cm}$ between the plants.

Recommended agronomic practices and plant protection measures were followed for raising good crop at each location. Observations were recorded on five randomly selected plants from each genotype in all the three replications for Number of branches per plant, Number of pods per plant, Pod weight per plant, 100 seed weight (g), Seed yield (q/ha). The data were statistically analyzed and the genotypes were assessed for their stability of performance across environments following the method described by Eberhart and Russell (1966) using computer software written in "WINDOSTAT".

\section{Results and Discussion}

Pooled analysis of variance revealed that mean sum of squares due to genotypes was highly significant for all the characters indicating presence of variability among the genotypes. The mean sum of square due to environment was also highly significant for all the characters indicating diverse nature of environments. The genotype $\mathrm{x}$ environment interaction was non-significant for all the characters except for number of pods per plant, indicating consistent performance of the genotypes across variable environments, due to the incidence of rust at all the three locations. The additive environmental variance was found to be of considerable magnitude as indicated by the significance of environment (linear) for all the characters (Table 1).

$\mathrm{G} \times \mathrm{E}$ (linear) component of interaction was non-significant for all the characters studied except for number of pods per plant and 100 seed weight indicating non-significant role of linear response of the genotypes to environmental changes. The pooled deviation was also non-significant for all the characters except for seed yield $(\mathrm{q} / \mathrm{ha})$ indicating the predominance of linear component of $\mathrm{G} \times \mathrm{E}$ interaction. Similar findings were reported earlier in soybean by Chandrakar et al., (1998), Islam et al., (2005), Mandal et al., (2005), Ramana and Satyanarayana (2005) and Pan et al., (2007).

The mean values for yield and its components, regression coefficient (bi), and deviation from regression $\left(S^{2} \mathrm{di}\right)$ for 13 genotypes over three environments are presented in table 2 . 
Table.1 Analysis of variance for stability for yield and yield components in soybean

\begin{tabular}{|c|c|c|c|c|c|c|}
\hline \multirow{2}{*}{$\begin{array}{l}\text { Source of } \\
\text { variation }\end{array}$} & \multirow[b]{2}{*}{ d.f } & \multicolumn{5}{|c|}{ Mean sum of squares for different characters } \\
\hline & & $\begin{array}{c}\text { Number of branches } \\
\text { per plant }\end{array}$ & $\begin{array}{c}\text { Number of pods } \\
\text { per plant }\end{array}$ & $\begin{array}{l}\text { Pod weight per } \\
\text { plant (g) }\end{array}$ & 100 seed weight $(\mathrm{g})$ & Seed yield (q/ha) \\
\hline Genotypes $(\mathrm{G})$ & 12 & $0.21 * *$ & $205.76^{* *}$ & $145.97 * *$ & $4.60 * *$ & $68.68 * *$ \\
\hline Environment(E) & 2 & $1.19 * *$ & $4250.35 * *$ & $962.82 * *$ & $4.85 * *$ & $46.54 * *$ \\
\hline $\begin{array}{ll}\text { Genotypes } & \mathrm{x} \\
\text { Environment } & \end{array}$ & 24 & 0.017 & $7.48^{*}$ & 0.34 & 0.002 & 4.29 \\
\hline $\begin{array}{l}\text { Environment } \\
\text { (linear) }\end{array}$ & 1 & $2.39 * *$ & $8500.71 * *$ & $1925.65 * *$ & $9.71 * *$ & $93.09 * *$ \\
\hline G X E(linear) & 12 & 0.01 & $12.69 * *$ & 0.24 & $0.003 *$ & 3.97 \\
\hline Pooled deviation & 13 & 0.02 & 2.09 & 0.41 & 0.001 & $4.25 * *$ \\
\hline Pooled error & 72 & 0.01 & 3.03 & 1.41 & 0.017 & 1.32 \\
\hline
\end{tabular}

$*=$ Significant at 5\%; ** = Significant at $1 \%$

Table. 2 Stability parameters for five characters in 13 advanced breeding lines of soybean

\begin{tabular}{|c|c|c|c|c|c|c|c|c|c|c|c|c|c|c|c|c|}
\hline \multirow[t]{2}{*}{$\begin{array}{c}\text { S. } \\
\text { No. }\end{array}$} & \multirow[t]{2}{*}{ Genotypes } & \multicolumn{3}{|c|}{ Number of branches/plant } & \multicolumn{3}{|c|}{$\begin{array}{c}\text { Number of pods per } \\
\text { plant }\end{array}$} & \multicolumn{3}{|c|}{ pod weight per plant (g) } & \multicolumn{3}{|c|}{100 seed weight $(\mathrm{g})$} & \multicolumn{3}{|c|}{ seed yield per ha $(q)$} \\
\hline & & Mean & bi & $S^{2}$ di & Mean & bi & $\mathbf{S}^{2} \mathbf{d i}$ & Mean & bi & $\mathbf{S}^{2} \mathrm{di}$ & Mean & bi & $S^{2} \mathrm{di}$ & Mean & $\mathbf{B i}$ & $S^{2}$ di \\
\hline 1 & $\mathrm{DSb} 21$ & 4.37 & 0.59 & 0.01 & 32.01 & 1.02 & -1.28 & 59.57 & 0.91 & -2.38 & 13.43 & 0.98 & -0.02 & 21.45 & 1.70 & 2.85 \\
\hline 2 & DSb 23-2 & 4.34 & 1.11 & -0.01 & 34.02 & 0.96 & -1.33 & 59.63 & 0.89 & -2.89 & 13.01 & 0.98 & -0.02 & 22.37 & 2.12 & $9.11 * *$ \\
\hline 3 & DSb 28-3 & 4.12 & $1.18+$ & -0.02 & 31.59 & 1.01 & -1.04 & 54.07 & 0.87 & -1.37 & 13.33 & 0.98 & -0.02 & 20.99 & 1.29 & -0.56 \\
\hline 4 & Line No. 9-1 & 3.87 & 1.14 & -0.02 & 28.57 & 0.97 & -1.33 & 49.90 & 0.85 & 1.28 & 11.07 & 0.98 & -0.02 & 18.06 & -0.08 & $8.40 * *$ \\
\hline 5 & Line No. 9-2 & 4.06 & 0.76 & $0.06 *$ & 26.58 & $0.94+$ & -1.36 & 44.83 & 0.85 & -1.57 & 11.27 & 0.98 & -0.02 & 18.03 & 0.32 & 2.54 \\
\hline 7 & Line No. 30-2 & 4.24 & 1.21 & -0.02 & 22.67 & 1.00 & -0.94 & 45.29 & 1.01 & -2.53 & 13.37 & 0.98 & -0.02 & 13.24 & 0.01 & $6.92 * *$ \\
\hline 8 & Line No. 15-3-2 & 4.39 & 0.54 & 0.03 & 21.09 & 1.02 & -1.04 & 51.27 & 1.10 & -2.92 & 12.00 & 0.98 & -0.02 & 13.27 & 0.68 & -0.40 \\
\hline 9 & EC 241780(P) & 4.20 & 0.93 & 0.01 & 17.62 & 1.01 & -0.67 & 45.74 & 1.17 & -2.38 & 11.63 & 0.98 & -0.02 & 10.97 & 0.37 & 2.04 \\
\hline 10 & EC 241778(P) & 4.37 & 1.09 & $0.06^{*}$ & 19.89 & 0.93 & -1.31 & 46.80 & $0.93+$ & -2.96 & 12.37 & 0.98 & -0.02 & 12.80 & 1.05 & -1.24 \\
\hline 11 & $\mathrm{DSb} 12(\mathrm{P})$ & 3.88 & 1.11 & -0.01 & 14.48 & 1.04 & -0.95 & 40.70 & 1.30 & $13.59 *$ & 9.50 & 0.98 & -0.02 & 10.67 & 2.29 & $12.48 * *$ \\
\hline 12 & JS 93-05(P) & 3.51 & 1.00 & 0.00 & 12.49 & 1.01 & 0.62 & 32.33 & 1.13 & -1.54 & 10.23 & 0.98 & -0.02 & 7.79 & 1.27 & -0.66 \\
\hline 13 & JS 335(P/C) & 3.78 & 1.21 & -0.02 & 16.80 & 1.07 & -0.57 & 34.23 & 1.03 & -2.89 & 11.16 & 1.22 & -0.01 & 9.86 & 1.00 & -1.26 \\
\hline
\end{tabular}

+ Significantly deviating from one at $5 \%$;

* Significantly deviating from zero at $5 \%$; ** significantly deviating from zero at $1 \%$ 
Based on the stability parameters for seed yield per ha genotypes DSb 21, DSb 28-3, Line No. 9-2 and Line No. 9-3 recorded higher mean performance coupled with non-significant regression coefficient and lower deviation from regression, suggesting stability of these genotypes across environments for the expression of the trait. The two genotypes viz., DSb 23-2 and Line No.9-1 exhibited high mean performance with non-significant bi value less than unity indicating its suitability to unfavorable environments, but they differed significantly from deviation regression value indicating they are unstable i.e., genotype performance cannot be predictable. Similar results were also reported by Taware et al., (1994), Major Singh (1995), Basavaraja et al., (1998), Chandrakar et al., (1998), Hossain et al., (2003), Raut et al., (2003), Islam et al., (2005), Ramana and Satyanarayana (2005) and Pan et al., (2007). On the basis of stability analysis of individual characters, the genotype DSb 21 was identified as stable genotype for all the characters studied with higher mean across environments. For seed yield, genotype DSb 232 was high yielder across environments compared to the check JS 335.On the basis of stability parameters DSb 21 was identified as stable genotype for all the characters studied with higher mean performance across three environments. Therefore could be used in the breeding programme for the development of high yielding stable genotypes over environments for future use. However, DSb 23 2 was the highest yielder across environments.

\section{References}

Alghamdi, S.S., 2004. Yield stability of some soybean genotypes across diverse environments. Pakistan Journal of Biological Sciences, 7(12): 2109-2114.
Baker, R.J., 1988. Tests for crossover genotype x environment interactions. Can. J. Plant Sci. 68:405-410.

Chandrakar, P.K., Rajeev Shrivastava, Agarwal SK and Rao SS. 1998. Stability analysis of Soybean varieties in rice zone of Madhya Pradesh. J. Oilseeds Res., 15(2): 247-249.

Eberhart, S.A., and Russell WL. 1966. Stability parameters for comparing varieties. Crop Sci., 6: 36-40.

Islam, M.S., Newaz M.A., and Rahman J. 2005. Genotype- Environment interaction for seed yield and yield contributing characters in Soybean. Int. J. Sus. Agric. Tech. 1 (3): 2024.

Kang, M.S., 1998. Using genotype-byenvironment interaction for crop cultivar development. Adv. Agron., 35:199-240.

Mandal, S., Chettri M. and Nath R. 2005. Stability of Soybean lines for yield and yield attributing traits in hill zone of West Bengal. Indian J. Agril. Sci., 75 (2): 106108.

Pan, R.S., Singh, A.K. Kumar S. and Mathura Rai. 2007. Stability of yield and its components in Vegetable Soybean. Indian J. Agril. Sci., 77 (1): 88-91.

Parameshwar, M., 2006.Genetic investigations in soybean (Glycine max (L.) Merrill). M.Sc (Agri.) Thesis, Univ. Agric. Sci., Dharwad.

Ramana, M.V., and Satyanarayana AJ. 2005. Stability analysis for yield and component traits in Soybean. J. Oilseeds Res., 22 (1):18-21.

Singh, R.J., and Hymowitz T. 2001. Exploitation of wild potential Glycine species for improving the soybean. In: Bhatnagar P. S. (ed.), Proceedings of India Soy Forum, pp 58-61.

Taware, S.P., Raut VM, Halvankar GB and Patil VP. 1994. Phenotypic stability analysis of Soybean variety in Kharif and summer seasons. J. Oilseeds Res. 11 (2): 237-241

\section{How to cite this article:}

Shruti Koraddi, G.T. Basavaraja and Ishwar Bhoodi. 2017. Stability Analysis in Soybean [(Glycine max L.) Merrill]. Int.J.Curr.Microbiol.App.Sci. 6(9): 945-948. doi: https://doi.org/10.20546/ijcmas.2017.609.113 